\title{
PENERAPAN MODEL PEMBELAJARAN KOOPERATIF TIPE TAI (TEAM ASSISTED INDIVIDUALIZATION) DENGAN TEKNIK TUTOR SEBAYA DALAM PEMBELAJARAN BIOLOGI SMA
}

\author{
Rahmat Hidayat $^{1)}$, Tjandrakirana ${ }^{2}$, Wahono Widodo ${ }^{3)}$ \\ ${ }^{1)}$ Mahasiswa Program Studi Pendidikan Sains, Program Pascasarjana Universitas Negeri Surabaya \\ ${ }^{2), 3)}$ Dosen Pascasarjana Prodi Pendidikan Sains Univesrtitas Negeri Surabaya
}

\begin{abstract}
After doing research by using 5E Learning Cycle Model through Guided Discovery learning with the topic of Human Reproduction System, it aimed to increase the student learning outcomes. The subjects were 35 students of SMA Negeri 4 Samarinda, which used One group pretest-posttest design. The data were analyzed by using quantitative-qualitative description, the results are : (1) The feasibility of lesson plan categorized as good; (2) Student activity with a good instrument reliability; (3) Student learning outcomes had increased with the average score was 85 (N-gain score was 0,76$)$. According to analyzed data, it can be concluded that 5E Learning Cycle Model through Guided Discovery can be used to increase student learning outcomes.
\end{abstract}

Keywords: 5E Learning Cycle Model, Student Learning Outcomes

Abstrak: Telah dilakukan penelitian dengan menggunakan model pembelajaran Learning Cycle 5E berbasis Guided Discovery pada pokok bahasan Sistem reproduksi manusia, dengan tujuan meningkatkan hasil belajar siswa. Subyek penelitian 35 siswa SMA Negeri 4 Samarinda menggunakan rancangan One Group Pretest and Postest Design. Data adalah hasil kompetensi pengetahuan, keterampilan dan sikap. Data tersebut dianalisis dengan hasil sebagai berikut: (1) Keterlaksanaan RPP dengan kategori baik; (2) aktivitas siswa dengan realibilitas instrumen berkategori baik; (3) THB untuk mengetahui peningkatan hasil belajar siswa terhadap materi sistem reproduksi manusia dengan rata-rata skor 85 yang secara keseluruhan mengalami peningkatan Gain 0.76. Berdasarkan hasil analisis dapat disimpulkan bahwa Model Learning Cycle 5E berbasis Guided Discovery dapat digunakan untuk meningkatkan hasil belajar siswa.

Kata kunci: Model Learning Cycle 5E, Hasil Belajar Siswa.

\section{PENDAhuluan}

Pendidikan mempunyai peranan yang sangat penting dalam kehidupan, baik dalam kehidupan seseorang, keluarga masyarakat, maupun bangsa dan negara. Banyak upaya yang dilakukan para pelaku pendidik dalam meningkatkan mutu pendidikan. Pembaharuan kurikulum, penerapan model pembelajaran yang diadopsi dari Negara maju, peningkatan keefektifan bahan ajar agar materi mudah ditangkap oleh siswa, dan perubahan fasilitas pembelajaran. Permendiknas No. 65 Tahun 2013 tentang standar proses Pendidikan Dasar dan Menengah telah mengisyaratkan tentang perlunya proses pembelajaran yang dipandu dengan kaidah-kaidah pendekatan scientific approach. Upaya penerapan pendekatan scientific approach dalam proses pembelajaran ini sebagai ciri khas dan menjadi kekuatan tersendiri dari keberadaan kurikulum 2013. Proses pembelajaran harus menyentuh tiga ranah, yaitu sikap, pengetahauan dan keterampilan.

Ketercapain kurikulum 2013 memerlukan suatu model pembelajaran yang sesuai dengan scientific approach, karena dapat membantu siswa untuk mengembangkan pemahaman tentang konsep ilmiah, dengan mengesplorasi dan memperdalam pemahaman tersebut, dan kemudian menerapkan konsep pada situasi yang baru, sehingga pembelajaran tersebut efektif untuk meningkatkan sikap, prestasi dan keterampilan berfikir ilmiah.

Model pembelajaran Learning Cycle $5 E$ merupakan salah satu model pembelajaran yang menerapkan prinsip-prinsp konstruktivisme yang mengacu pada scientific approach. Model ini berpusat pada peserta didik, yang beranggapan bahwa dalam belajar pengetahuan itu dibangun sendiri oleh anak dalam struktur kognitif melalui interaksi dengan lingkungannya. Menurut Bybee (1996), tahapantahapan model Learning Cycle $5 E$ adalah: Engangement, Exploration, Explanation, Elaboration, dan Evaluation. Setiap tahap kegiatan dalam model Learning Cycle 5E memberikan kesempatan kepada siswa secara aktif membangun konsep-konsepnya 
sendiri dengan cara berinteraksi dengan lingkungan fisik maupun sosial.

Hasil penelitian yang dilakukan Verawati (2013) tentang pengembangan perangkat pembelajaran berbasis model Learning Cycle $5 E$ dapat meningkatkan penguasaan konsep dan keterampilan berpikir kritis siswa SMK pada materi laju reaksi. Pada penelitian terdahulu Tika (2008) untuk remediasi konsep listrik arus searah siswa menggunakan Learning Cycle $5 E$ dengan bahan ajar bermuatan model perubahan konseptual dalam pembelajaran fisika. Sejalan dengan hal tersebut, mungkin model Learning Cycle 5E dapat diterapkan dalam pembelajaran biologi, karena pokok bahasan dalam biologi banyak menuntut siswa untuk berpikir dan bernalar secara konkrit dan abstrak, salah satunya pada materi sistem reproduksi pada manusia dengan kompetensi dasar menganalisis hubungan antara struktur jaringan penyusun organ reproduksi dengan fungsinya dalam proses reproduksi manusia melalui studi literatur, pengamatan dan percobaan.

Sistem reproduksi sangat esensial dalam kehidupan individu dalam mempertahankan spesies agar tidak punah. Materi ini mempelajari struktur dan fungsi reproduksi pada manusia yang paling sensitif dalam ukuran norma dan agama, untuk memahami sistem reproduksi pada manusia tidak hanya meliputi struktur dan fungsi organ-organ reproduksi, tetapi juga bagaimana organ reproduksi menghasilkan dan menyimpan sel-sel gamet kemudian menggabungkan untuk membentuk individu baru serta mekanisme hormonal yang berperan dalam memelihara fungsi reproduksi secara normal. Melihat karakteristik materi sistem reproduksi manusia yang memiliki konsepkonsep abstrak bahkan beberapa siswa sulit membayangkan bagaimana cara kerja sistem tersebut dan bagaimana proses fertilisasi terjadi. Terkait dengan ini, model Learning Cycle $5 E$ kemungkinan dapat membantu untuk memecahkan permasalahan secara ilmiah atau bekerja secara ilmiah karena melalui proses eksplorasi siswa akan terlibat langsung dalam mengeksplor materi secara bebas dengan melakukan berbagai kegiatan ilmiah seperti mengamati, membandingkan, mengelompokkan, menginterpretasi kan, dan yang lainnya, sehingga menemukan konsepkonsep penting tentang sistem reproduksi manusia.

Konsep yang ditemukan sudah sesuai dengan konsepsi awal siswa sehingga langsung diasimilasikan dalam struktur kognitifnya tetapi ada juga konsep yang tidak sesuai sehingga menimbulkan konflik kognitif, melalui diskusi dan bertanya pada teman maupun guru, siswa mengakomodasikan konsep sistem reproduksi pada manusia untuk dapat diasimilasikan, dengan cara demikian siswa mengembangkan pengetahuan yang dimilikinya. Tahap pengenalan konsep guru membantu siswa mengidentifikasi konsep, prinsip, dan hukum- hukum yang berhubungan dengan pengalaman pada fase eksplorasi , kemudian menerapkan konsep yang baru mereka pahami untuk memecahkan masalahmasalah dalam situasi yang berbeda. Kekurangan lain mungkin muncul karena ketidakmampuan memvisualisasikan fenomena yang tidak teramati dan beberapa siswa tidak dapat melihat bagaimana konsep sistem reproduksi manusia bekerja tanpa bantuan gambar/torso (Bean et al, 1996).

Pendekatan Learning Cycle 5E dapat diciptakan kesempatan untuk memberikan pengalaman fisik, interaksi sosial dan regulasi sendiri, yang dapat memberikan keuntungan pada siswa untuk belajar. Pendekatan ini akan membawa banyak daya tarik dan akses untuk membuat konsep-konsep yang awalnya sulit dimengerti, karena tidak dapat divisualisasikan dalam pikiran siswa tentang bagaimana sistem reproduksi tersebut bekerja menjadi mudah untuk dimengerti. Atas dasar itu maka akan dilakukan penelitian dengan menggunakan model learning cycle $5 \mathrm{E}$ berbasis guided discovery untuk membantu siswa mempelajari biologi khususnya pada materi sistem reproduksi manusia dalam memberikan pemahaman mendalam tentang konsep kepada siswa tentang sistem reproduksi manusia.

\section{METODE PENELITIAN}

Penelitian ini merupakan penelitian pra eksperimen, karena ada perlakuan, tanpa kontrol, dan pengulangan dengan menerapkan perangkat pembelajaran yang telah dikembangkan terdiri dari Rencana Pelaksanaan Pembelajaran (RPP), Buku Ajar Siswa (BAS),Lembar Kegiatan Siswa (LKS), dan Tes Hasil Belajar (THB).

Desain dalam penelitian ini merupakan penelitian pra eksperimen menggunakan One Group Pretest and Postest Design yang dikembangkan oleh Cambell \& Stanley dalam Arikunto sebagai berikut:

$$
\begin{array}{lll}
\mathrm{O}_{1} & \mathrm{x} & \mathrm{O}_{2}
\end{array}
$$

Dengan:

$$
\begin{aligned}
& \mathrm{O}_{1}=\text { Uji awal (Pre test) } \\
& \mathrm{O}_{2}=\text { Uji akhir (Post test) } \\
& \mathrm{X}=\text { Perlakuan }
\end{aligned}
$$

Subjek dalam penelitian ini adalah 35 siswa kelas XI IPA SMA Negeri 4 Samarinda. Bahan kajian yang menjadi sasaran penelitian adalah materi sistem reproduksi manusia.

Variabel Penelitian

1) Variabel bebas: Model Pembelajaran Learning Cycle $5 E$ berbasis Guided Discovery

2) Variabel terikat: Keterlaksanaan rencana pelaksanaan pembelajaran, aktivitas siswa, respon siswa, dan hasil belajar. 
Penelitian ini terdiri dari 2 tahap. Tahap persiapan, yaitu tahapan pengembangan perangkat pembelajaran dan tahap implementasi di kelas. Prosedur penelitian menggunakan pengembangan perangkat model 4D (Four D model). Model ini sebelumnya telah dikembangkan oleh Thiagarajan, Semmel and Semmel (1974). Proses pengembangan perangkat ini terdiri dari empat tahap, yaitu pendefenisian (define), perancangan (design), pengembangan (develop), dan penyebaran (disseminated). Alur pada perancangan perangkat pembelajaran dengan menggunakan model 4D.

Kegiatan yang dilakukan pada tahap persiapan adalah menyiapkan perangkat pembelajaran dan instrumen penelitian berupa RPP, Buku ajar siswa, LKS, dan THB . yang akan digunakan dalam penilitian. Perangkat pembelajaran yang telah selesai dibuat selanjutnya dikonsultasikan dengan validator untuk menguji validitasnya dan digunakan dalam uji coba 1 dan 2.

Validasi perangkat yang meliputi Rencana Pelaksanaan Pembelajaran, Buku Ajar Siswa, Lembar Kegiatan Siswa dan Tes Hasil Belajar dengan hasil baik dan layak digunakan.

Tahap pelaksanaan Uji coba perangkat pada 35 siswa SMA kelas XI IPA SMA Negeri 4 Samarinda, Pada tahap ini peneliti bertindak sebagai pengajar dan siswa sebagai kelompok eksperimen. Pelaksanaan penelitian dimulai dengan mengadakan tes awal (pretest), kegiatan pembelajaran yang menerapkan model Learning Cycle 5E berbasis Guided Discovery dan uji akhir (posttest). Selama pembelajaran berlangsung dilakukan juga observasi terhadap kemampuan guru dalam mengelola Kegiatan Pembelajaran, yang dilakukan apakah sesuai dengan sintaks dalam RPP dan aktivitas siswa selama mengikuti proses pembelajaran. Selanjutnya diakhir pembelajaran siswa diberikan angket respon siswa untuk mengetahui reaksi siswa terhadap pelaksanaan kegiatan bealahr mengajar.

Penelitian pelaksanaan pembelajaran di kelas digunakan sebagai validasi empirik untuk mencari data respon, reaksi atau komentar siswa dan pengamat. Hasil penelitian ini dianalisis, kemudian digunakan untuk penyusunan laporan akhir sehingga menghasilkan naskah perangkat ajar yang siap diimplementasikan pada tahap penyebaran (Dissiminate).

Penerapan perangkat pembelajaran di kelas dilaksanakan sesuai jadwal yang telah disusun oleh sekolah dengan alokasi waktu 8 kali pertemuan ( 8 jam tatap muka).

Instrumen yang digunakan dalam penelitian adalah alat bantu yang digunakan untuk mengumpulkan data yang diperoleh dari proses penelitian. Diantaranya adalah:
1. Lembar Pengamatan Keterlaksanaan RPP (LPK RPP), digunakan untuk mengamati kemampuan guru mengelola kegaitan belajar mengajar (KBM) dan keteralaksanaan KBM sesuai urutan sitaks yang tertuang pada RPP.

2. Lembar Pengamatan Aktivitas Siswa (LP AS), digunakan untuk mendapatkan data pengamatan selama kegiatan Pembelajaran berlangsung dengan menerapkan model LC 5E berbasis Guided Discovery pada materi sistem reproduksi manusia.

3. Lembar Angket Respon Siswa (LARS), digunakan untuk mengetahui tanggapan siswa terhadap perangkat pembelajaran dan model pembelajaran yang dipergunakan guru selama kegiatan penelitian berlangsung.

4. Tes Hasil Belajar (THB), digunakan untuk mengetahui peningkatan hasil belajar siswa secara individu dan klaksikal setelah mengikuti pembelajaran materi sistem reproduksi manusia dengan model Learning Cycle $5 E$ berbasis Guided Discovery.

Teknik yang digunakan untuk mengumpulkan data adalah melalui observasi, pemberian tes, dan pemberian angket. Analisis data dilakukan dengan menggunakan teknik deskriptif kualitatif.

\section{HASIL PENELITIAN DAN DISKUSI}

Penelitian ini bertujuan menerapkan suatu perangkat pembelajaran model Learning Cycle $5 E$ berbasis Guided Discovery pada materi pokok sistem reproduksi manusia. Kegiatan penelitian didahului dengan validasi perangkat pembelajaran, dengan tujuan untuk mengetahui validitas perangkat pembelajaran yang akan diterapkan, yaitu meliputi validitas RPP, BAS, LKS, dan THB. Hasil validasi RPP, BAS, LKS dan THB oleh pakar adalah berkategori baik dengan sedikit revisi. Hasil penerapan perangkat pembelajaran model Learning Cycle 5E berbasis Guided Discovery pada materi pokok sistem reproduksi manusia akan diperoleh data tentang keterlaksanaan RPP, aktivitas siswa, respon siswa, hasil belajar siswa selama pembelajaran.

\section{A. Hasil Penerapan Perangkat Pembelajaran Learning Cycle $5 E$ berbasis Guided Discovery}

\section{Keterlaksanaan RPP}

Pengamatan keterlaksanaan RPP selama uji perangkat dilakukan oleh empat orang pengamat, namun dalam hal ini setiap kegiatan pembelajaran dilakukan pengamatan masing-masin dua orang pengamat. Rekapitulasi hasil perhitungan keterlaksanaan RPP dapat dilihat pada table 1 .

Tabel 1. hasil perhitungan keterlaksanaan RPP 


\begin{tabular}{|c|c|c|c|c|c|c|c|c|c|}
\hline \multirow{2}{*}{ No } & \multirow{2}{*}{$\begin{array}{c}\text { Aspek yang } \\
\text { Diamati }\end{array}$} & \multicolumn{6}{|c|}{ Rata-rata Penilian RPP Perpertemuan } & \multirow[b]{2}{*}{ Rata-rata } & \multirow[b]{2}{*}{ Kategori } \\
\hline & & 1 & 2 & 3 & 4 & 5 & 6 & & \\
\hline \multicolumn{10}{|c|}{ A. Pendahuluan } \\
\hline 1. & Engagement & 4,8 & 4,8 & 4,8 & 4,8 & 5 & 4,8 & 4,8 & SB \\
\hline \multicolumn{10}{|c|}{ B. Kegiatan Inti } \\
\hline 2 & Exploration & 4,5 & 4,5 & 4,8 & 5 & 4,5 & 4,8 & 4,7 & SB \\
\hline 3 & Explanation & 4,2 & 4,5 & 4 & 4,2 & 4,5 & 4 & 4,2 & $\mathrm{~B}$ \\
\hline 4 & Elaboration & 4 & 4 & 4,5 & 4,5 & 4,5 & 4 & 4,2 & B \\
\hline 5 & Evaluation & 4,2 & 4,2 & 4 & 4,2 & 4,2 & 4,2 & 4,2 & $\mathrm{~B}$ \\
\hline \multicolumn{2}{|c|}{ C.Penutup } & 4 & 5 & 4 & 4 & 5 & 4 & 4,3 & B \\
\hline \multicolumn{2}{|c|}{ Suasana Kelas } & 4,3 & 4,4 & 4,2 & 4,4 & 4,1 & 4,2 & 4,3 & B \\
\hline \multicolumn{2}{|c|}{ Alokasi Waktu } & 4 & 3,5 & 4 & 3,5 & 3 & 3 & 3,5 & $\mathrm{~B}$ \\
\hline \multicolumn{2}{|c|}{ Reliabilitas } & 80 & 78 & 83 & 78 & 75 & 8 & 80 & \\
\hline
\end{tabular}

Berdasarkan Tabel 1 data-data tersebut dapat diketahui bahwa rata-rata seluruh langkah-langkah pembelajaran yang tertulis dalam RPP telah terlaksana dengan hasil baik. Rata-rata reliabilitas yang dihasilkan adalah 79,6 hal ini menunjukkan bahwa presentase kococokan penilaian antara pengamat pertama dan kedua adalah baik.

Hasil analisis menunjukkan bahwa pengelolaan pembelajaran dengan menggunakan model pembelajaran learning cycle $5 E$ berbasis guided discovery pada siswa SMA secara keseluruhan sudah terlaksana dengan baik, pada aspek kegiatan pendahuluan, kegiatan inti, kegiatan penutup, dan suasana kelas dalam kategori baik. Kondisi ini disebabkan kegiatan pembelajaran selalu mengacu pada RPP yang telah dipersiapkan secara matang, tersusun rapi dan berurutan. Hal ini sesui dengan prinsip-prinsip pengembangan RPP Permendikbud No. 81 A Lampiran IV yang menyatakan bahwa RPP disusun sebagai terjemahan dari ide kurikulum dan berdasarkan silabus yang telah dikembangkan di tingkat nasional ke dalam bentuk rancangan proses pembelajaran untuk direalisasikan dalam pembelajaran. RPP yang diterapkan menyesuaikan apa yang dinyatakan dalam silabus dengan kondisi di satuan pendidikan baik kemampuan awal pesertadidik, minat, motivasi belajar, bakat, potensi, kemampuan sosial, gaya belajar, latar belakang budaya, norma/nilai dan lingkungan peserta didik, serta mendorong peserta didik prtisipasi aktif pesertadidik untuk terlaksananya proses pembelajaran yang efektif dan efisien .

Hasil penilaian terhadap kemampuan guru dalam mengelola KBM dan keterlaksanaan RPP dapat dilihat pada Tabel 1. Berdasarkan Tabel 1 keterlaksanaan RPP menunjukkan kemampuan guru dalam mengelola pembelajaran pada masing-masing aspek yang diamati pada tahap engagement baik pertemuan 1 sampai pertemuan 6 berkategori sangat baik dengan nilai ratarata di atas 4.79, hal ini menunjukkan bahwa guru sudah membuka kegiatan pembelajaran dengan baik, menggunakan pertanyaan-pertanyaan yang didasarkan pada pengetahuan awal siswa dan memacu keingin tahuan siswa sesuai dengan model larning cycle $5 E$ berbas gisuided discovery yang digunkan sehingga siswa termotivasi untuk mengikuti kegiatan selanjutnya. Kegitan inti yang terdiri dari 4 fase yaitu exploration, explanation elaboration dan evaluation berkategori baik dengan nilai rata-rata 4,35, karena guru mengelola pembelajaran dengan baik sesuai dengan sintaks model pembelajran learning cycle $5 E$ berbasis guided discovery, serta membimbing siswa menyelesaikan tugas yang diberikan dan guru memberi dorongan agar siswa berbuat banyak dan kreatif. Hal ini sejalan dengan pendapat Arends (1997) yang menyatakan bahwa peran guru bukan hanya membagikan pengetahuan dan kebenaran namun juga berperan sebagai penuntun dan pemandu, pada prinsifnya, keseluruhan proses pembelajaran membantu siswa menjadi mandiri, percaya diri, aktif dan yakin pada kemampuan intelektualnya sendiri secara aktif.

Kegiatan inti pada pelaksanaan RPP pertemuan 1 sampai pertemuan 6 berkategori baik, hal ini dikarenakan guru tidak mengabaikan salah satu hal yang penting yaitu mengecek seberapa jauh pemahaman siswa terhadap materi yang diajarkan dengan baik. Mengecek pemahaman siswa adalah hal penting yang harus diperhatikan oleh guru selama kegiatan belajar mengajar yang bertujuan untuk mengetahui pemahaman siswa terhadap materi yang diajarkan, selain itu siswa menjadi lebih perhatian. Hal ini sejalan dengan pendapat Gagne (1988) yang menyatakan bahwa rangsangan yang mendapat perhatian dan dikenali dan kemudian dipindahkan ke short term memory (ingatan jangka pendek), suatu tempat penyimpanan yang memiliki kapasitas terbatas. Adanya serangkaian kerja mental berupa pengulangan, dan pemecahan masalah, informasi tersebut dapat dipindahkan ke long term memory (ingatan jangka panjang). Sejalan dengan hasil penelitian yang telah dilakukan oleh MacKenzie White (1982) dalam Slavin (2009), keterlibatan siswa secara aktif dalam pembelajaran dapat meningkatkan penyimpanan informasi dalam memori jangka panjang.

Berdasarkan data keterlaksanaan RPP pertemuan 1 sampai pertemuan 6 kegiatan penutup dengan nilai rata- 
rata 4,33 kriteria baik. Guru dalam kegiatan penutup bertindak sebagai pemandu dalam melibatkan siswa secara aktif untuk menyimpulkan hasil belajar yang mengacu pada indikator dan memberikan tugas rumah untuk pertemuan selanjutnya, sehingga siswa tetap dijadikan kunci pembelajaran, sedangkan suasana kelas pelaksanaan RPP pertemuan 1 sampai pertemuan 6 dengan kriteria baik, hal ini menunjukkan bahwa guru menguasai konsep dan mampu membuat kesusaian sintaks dengan model pembelajaran dan mampu menciptakan suasana yang menyenangkan, dapat membangkitkan minat dan motivasi siswa, sehingga siswa mengikuti pembelajaan dengan antusias.

Pertemuan kelima dan keenam di tinjau dari segi pengelolaan waktu mempunyai nilai yang rendah yaitu 3 di banding penilaian pengelolaan waktu pertemuan yang lainnya, hal ini disebabkan pada pertemuan kelima siswa melakukan praktek tentang uji kehamilan, sehingga memerlukan waktu yang cukup lama, sedangkan pada pertemuan enam siswa melakukan presentasi hasil tugas proyek yang telah diberikan tentang ASI, KB dan kelainan pada sistem reproduksi manusia. Peran guru diperlukan dalam pengelolaan waktu, karena merencanakan pembelajaran diperlukan pengelolaan waktu yang disesuaikan dengan kedalaman materi dan keluasan materi, tingkat kepentingan dengan keadaan dan kebutuhan setempat.

Reliabilitas keterlaksanaan RPP pada pertemuan pertama sebesar $80,56, \%$, pertemuan kedua sebesar $77,78 \%$, pertemuan ketiga sebesar $83,33 \%$, pertemuan keempat sebesar 77,78, pertemuan kelima sebesar $75 \%$ dan pertemuan keenam sebesar $83,33 \%$. Reliabilitas instrumen pembelajaran masing-masing pertemuan memiliki rata-rata $79,63 \%$, sehingga dapat dikategorikan instrumen yang baik, hal ini menunjukkan bahwa presentase kecocokan penilaian antara pengamat pertama dan kedua adalah baik. Perhitungan reliabilitas instrumen yang digunakan menunjukkan bahwa instrumen yang digunakan dapat dipercaya karena memiliki reliabilitas melebihi $75 \%$, hal ini sesuai dengan nilai ketentuan yang diajukan oleh Borich (1994) dan Watkins (2001), bahwa instrumen pengamatan dikatakan reliabel jika memiliki reliabilitas diatas $75 \%$. Berdasarkan hasil enam kali pelaksanaan Rencana Pelaksanaan Pembelajaran (RPP) pada penelitian ini dapat disimpulkan bahwa keterlaksanaan RPP model learning cycle $5 E$ berbasis guided discovery menunjukkan konsistensinya. Hal ini berarti instrumen lembar pengamatan keterlaksanaan RPP yang digunakan reliabel.

Keterlaksanaan RPP yang baik, ini ditunjukkan dengan adanya peningkatan peningkatan hasil belajar siswa, yaitu ditunjukkan dengan peningkatan rata-rata nila gain sebesar 0,76 dengan kategori tinggi, hal ini sesuai dengan klasifikasi nilai yang diajukan oleh
Savinainen \& Scot (2002) bahwa peningkatan nilai gain dikatakan tinggi jika memiliki nilai gain > 0.70 . Apabila guru telah melaksanakan langkah-langkah pembelajaran yang terdapat dalam RPP dengan baik maka diperoleh hasil belajar yang memuaskan. Sebagaimana yang diungkapkan oleh Mulyasa (2013) bahwa tugas guru tidak hanya menyampaikan informasi kepada peserta didik, tetapi harus menjadi fasilitator yang bertugas memberikan kemudahan belajar (facilitate of learning) kepada seluruh pesert didik. Guru merancang pembelajaran dari awal sampai akhir dari sederhana sampai kompleks, selanjutnya bersama siswa meraih titik puncak kesuksesan pembelajaran.

\section{Aktivitas Siswa Selama Pembelajaran}

Aktivitas siswa selama kegiatan pembelajaran berlangsung diamati oleh 2 orang pengamat dengan menggunakan instrumen lembar pengamatan aktivitas siswa.

Tabel 2 menunjukkan presentase aktivitas siswa dalam pembelajaran model Learning cycle $5 E$ berbasis Guided discovery pada materi pokok sistem reproduksi manusia selama enam kali pertemuan.

Tabel 2. menunjukkan presentase aktivitas siswa dalam pembelajaran

\begin{tabular}{|c|c|c|}
\hline No. & Aktivitas Siswa & Rata-rata \\
\hline 1. & Mengajukan pertanyaan & $6,2 \%$ \\
\hline 2. & $\begin{array}{l}\text { Mengajukan ide atau pendapat } \\
\text { tentang pengetahuan awal siswa } \\
\text { terkait system reproduksi } \\
\text { manusia }\end{array}$ & $6,3 \%$ \\
\hline 3. & $\begin{array}{l}\text { Membaca (mencari informasi } \\
\text { dan sebagainya) }\end{array}$ & $25,5 \%$ \\
\hline 4. & $\begin{array}{l}\text { Melakukan diskusi kelompok } \\
\text { tentang teori organ reproduksi } \\
\text { manusia }\end{array}$ & $25,8 \%$ \\
\hline 5. & $\begin{array}{l}\text { Menyampaikan pendapat } \\
\text { mengkomunikasikan informasi } \\
\text { kepada kelas dan guru dalam } \\
\text { diskusi kelas }\end{array}$ & $6,7 \%$ \\
\hline 6. & $\begin{array}{l}\text { Menjawab pertanyaan atau } \\
\text { mampu memberikan alasan } \\
\text { dalam diskusi kelas }\end{array}$ & $7 \%$ \\
\hline 7. & Mengaplikasikan konsep & $6 \%$ \\
\hline 8. & $\begin{array}{l}\text { Mengerjakan evaluasi secara } \\
\text { mandiri untuk memantapkan } \\
\text { konsep tentang sistem organ } \\
\text { reproduksi manusia }\end{array}$ & $14,5 \%$ \\
\hline 9. & $\begin{array}{l}\text { Berperilaku yang tidak relevan } \\
\text { dalam kegiatan pembelajaran } \\
\text { (seperti percakapan yang tidak } \\
\text { perlu, mengerjakan sesuatu } \\
\text { yang tidak berkaitan dengan } \\
\text { proses pembelajaran, } \\
\text { mengganggu teman atau } \\
\text { melamun. }\end{array}$ & $2,3 \%$ \\
\hline
\end{tabular}




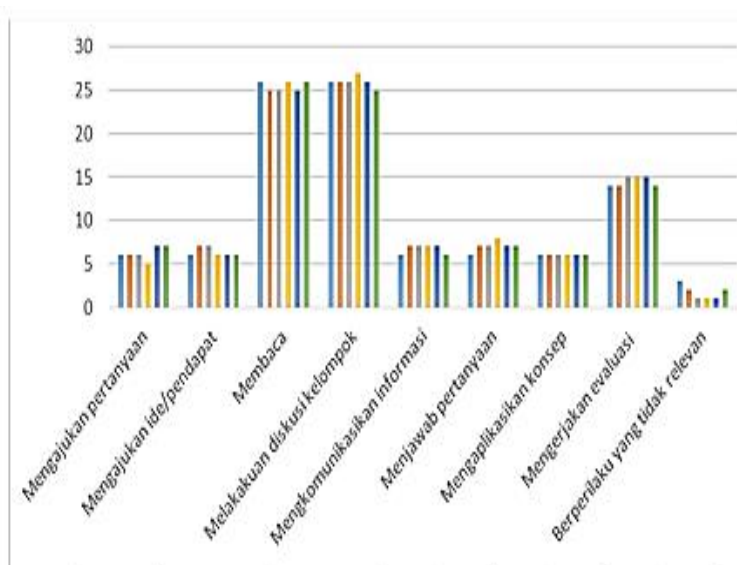

a Pertemuan 1 apertemuan 2 แ pertemuan 3 apertemuan 4 apertemuan 5 apertemuan 6

Gambar 1. Aktivitas Siswa dalam Pembelajaran LC 5E

Aktivitas siswa dalam penelitian ini merupakan rangkaian kegiatan yang di lakukan siswa dalam mengikuti pembelajaran. Pertemuan pertama dalam kegiatan pembelajaran, guru masih sering memberikan penjelasan-penjelasan karena siswa masih sangat memerlukan pengarahan atau bimbingan dalam mengerjakan LKS, di karenakan model pembelajaran learning cycle $5 E$ masih baru bagi siswa, pada pertemuan 2 sampai pertemuan 6 siswa mulai aktif bertanya pada guru, menyampaikan pendapat, dan aktif dalam diskusi kelompok maupun diskusi kelas dalam menyelesaikan tugas karena guru selalu memberikan umpan balik positif sehingga siswa merasa sangat dihargai dan guru selalu memotivasi siswa bahwa pembelajaran yang sedang dilakukan ada relevansinya dengan kebutuhan siswa.

Berdasarkan analisis data pada Tabel 2 dapat diketahui frekuensi aktivitas siswa dalam kegiatan pembelajaran sudah mencerminkan aktivitas yang sesuai dengan tahap-tahap pembelajaran dengan learning cycle $5 E$ berbasis guided discovery dengan persentasi engagement $6,2 \%$, exploration 25,6\%, explanation $6,8 \%$, elaboration $6 \%$ dan evaluation $14,5 \%$ dan aktivitas lain sebesar 2,3\%, hal ini menunjukkan bahwa selama enam kali pertemuan pembelajaran, sebagian besar waktu pembelajaran yang tersedia digunakan siswa untuk membaca (mencari informasi) menjawab pertanyaan atau memberikan alasan dalam diskusi kelas, menyampaikan pendapat/ mengkomunikasikan informasi kepada kelas dan guru dalam diskusi kelas.

Hasil analisis menunjukkan reliabilitas aktivitas siswa pada pertemuan pertama sebesar $97 \%$, pertemuan kedua sebesar $96 \%$, pertemuan ketiga sebesar $97 \%$, pertemuan keempat sebesar $97 \%$, pertemuan kelima sebesar $97 \%$ dan pertemuan keenam sebesar $96 \%$. Berdasarkan hasil reliabilitas ini menunjukkan bahwa frekuensi aktivitas siswa selama proses belajar siswa tergolong tinggi. Nilai koefisien reliabilitas instrumen tersebut melebihi $75 \%$ dengan demikian instrumen aktivitas siswa dalam kategori instrumen yang sangat baik atau reliabel. Sesuai dengan ketentuan dari Borich (1994) yang menyatakan bahwa suatu instrumen penilaian dikatakan reliabel jika memiliki nilai reliabilitas $\geq 0.75$ atau $75 \%$. Berdasarkan hasil tersebut, maka lembar pengamatan aktivitas siswa menunjukkan konsistensisnya.

Hasil analisis aktivitas siswa selama pembelajaran menunjukkan bahwa model learning cycle $5 E$ berbasis guided discovery terpusat pada siswa. Hal ini sesuai dengan harapan pemerintah yang terdapat dalam Permendikbud nomor 81 A tahun 2013 yang menegaskan bahwa prinsip pembelajaran berpusat pada siswa, mengembangkan kreativitas siswa, minciptakan kondisi belajar yang menyenangkan dan menantang serta menyediakan pengalaman belajar yang beragam melalui penerapan berbagai strategi dan metode pembelajaran yang menyenangkan, kontekstual, efekif, efisien dan bermakna.

\section{Respon Siswa}

Angket respon siswa digunakan untuk mengetahui respon, minat, pendapat dan penilaian siswa terhadap pelaksanaan kegiatan belajar mengajar model Learning cycle $5 E$ berbasis guided discovery. Rekapitulasi hasil angket respon siswa terhadap pembelajaran model Learning cycle $5 E$ berbasis guided discovery pada materi pokok sistem reproduksi manusia seperti pada Tabel 3.

Tabel 3. Rekapitulasi hasil angket respon siswa

\begin{tabular}{|c|c|c|c|}
\hline No. & Pertanyaan & Kriteria & $\begin{array}{l}\text { Perse } \\
\text { ntase }\end{array}$ \\
\hline \multirow[t]{4}{*}{1.} & \multirow{4}{*}{$\begin{array}{l}\text { Dengan Model } \\
\text { Pembelajaran Learning } \\
\text { cycle 5E berbasis Guided } \\
\text { discovery melalui metode } \\
\text { diskusi, Tanya jawab dan } \\
\text { eksperimen saya lebih } \\
\text { senang belajar dengan } \\
\text { langsung } \\
\text { mengaplikasikan } \\
\text { pelajaran atau materi } \\
\text { yang didapat. }\end{array}$} & $\begin{array}{l}\text { Sangat } \\
\text { Setuju }\end{array}$ & $69 \%$ \\
\hline & & Setuju & $31 \%$ \\
\hline & & $\begin{array}{l}\text { Tidak } \\
\text { Setuju }\end{array}$ & $0 \%$ \\
\hline & & $\begin{array}{l}\text { Sangat } \\
\text { Tidak } \\
\text { Setuju }\end{array}$ & $0 \%$ \\
\hline \multirow[t]{4}{*}{2.} & \multirow{4}{*}{$\begin{array}{lr}\text { Model } & \text { pembelajaran } \\
\text { learning cycle } & \text { 5E } \\
\text { berbasis guided discovery } \\
\text { membuat siswa lebih } \\
\text { berani mengemukakan } \\
\text { pendapatnya, sehingga } \\
\text { lebih cepat paham } \\
\text { terhadap materi yang } \\
\text { dipelajari. }\end{array}$} & $\begin{array}{l}\text { Sangat } \\
\text { Setuju }\end{array}$ & $71 \%$ \\
\hline & & Setuju & $29 \%$ \\
\hline & & $\begin{array}{l}\text { Tidak } \\
\text { Setuju }\end{array}$ & $0 \%$ \\
\hline & & $\begin{array}{l}\text { Sangat } \\
\text { Tidak } \\
\text { Setuju }\end{array}$ & $0 \%$ \\
\hline \multirow[t]{3}{*}{3.} & \multirow{3}{*}{\begin{tabular}{lr} 
Model & \multicolumn{2}{r}{ pembelajaran } \\
learning cycle berbasis \\
guided \\
membuat discovery \\
aktif dalam kegiatan
\end{tabular}} & $\begin{array}{l}\text { Sangat } \\
\text { Setuju }\end{array}$ & $60 \%$ \\
\hline & & Setuju & $40 \%$ \\
\hline & & $\begin{array}{l}\text { Tidak } \\
\text { Setuju }\end{array}$ & $0 \%$ \\
\hline
\end{tabular}




\begin{tabular}{|c|c|c|c|}
\hline No. & Pertanyaan & Kriteria & $\begin{array}{l}\text { Perse } \\
\text { ntase }\end{array}$ \\
\hline & pembelajaran & $\begin{array}{l}\text { Sangat } \\
\text { Tidak } \\
\text { Setuju }\end{array}$ & $0 \%$ \\
\hline \multirow[t]{4}{*}{4.} & \multirow{4}{*}{$\begin{array}{l}\text { Model Pembelajaran } \\
\text { learning cycle 5E } \\
\text { berbasis guided discovery } \\
\text { meningkatkan motivasi } \\
\text { belajar siswa }\end{array}$} & $\begin{array}{l}\text { Sangat } \\
\text { Setuju }\end{array}$ & $46 \%$ \\
\hline & & Setuju & $54 \%$ \\
\hline & & $\begin{array}{l}\text { Tidak } \\
\text { Setuju }\end{array}$ & $0 \%$ \\
\hline & & $\begin{array}{l}\text { Sangat } \\
\text { Tidak } \\
\text { Setuju }\end{array}$ & $0 \%$ \\
\hline \multirow[t]{4}{*}{5.} & \multirow{4}{*}{$\begin{array}{l}\text { Model pembelajaran } \\
\text { learning cycle 5E } \\
\text { berbasis guided discovery } \\
\text { membuat siswa lebih } \\
\text { mudah mengerjakan soal- } \\
\text { soal. }\end{array}$} & $\begin{array}{l}\text { Sangat } \\
\text { Setuju }\end{array}$ & $34 \%$ \\
\hline & & Setuju & $66 \%$ \\
\hline & & $\begin{array}{l}\text { Tidak } \\
\text { Setuju }\end{array}$ & $0 \%$ \\
\hline & & $\begin{array}{l}\text { Sangat } \\
\text { Tidak } \\
\text { Setuju }\end{array}$ & $0 \%$ \\
\hline \multirow[t]{4}{*}{6.} & \multirow{4}{*}{$\begin{array}{l}\text { Model pembelajaran } \\
\text { learning cycle 5E } \\
\text { berbasis guided discovery } \\
\text { dengan metode diskusi, } \\
\text { eksperimen, menarik dan } \\
\text { tidak membosankan. }\end{array}$} & $\begin{array}{l}\text { Sangat } \\
\text { Setuju }\end{array}$ & $69 \%$ \\
\hline & & Setuju & $31 \%$ \\
\hline & & $\begin{array}{l}\text { Tidak } \\
\text { Setuju }\end{array}$ & $0 \%$ \\
\hline & & $\begin{array}{l}\text { Sangat } \\
\text { Tidak } \\
\text { Setuju }\end{array}$ & $0 \%$ \\
\hline \multirow[t]{4}{*}{7.} & \multirow{4}{*}{$\begin{array}{l}\text { Dengan pembelajaran } \\
\text { model Learning cycle } 5 \mathrm{E} \\
\text { berbasis guided discovery } \\
\text { dapat meltih kemampuan } \\
\text { siswauntuk } \\
\text { menyelesaikan masalah } \\
\text { sendiri dengan bimbingan } \\
\text { guru. }\end{array}$} & $\begin{array}{l}\text { Sangat } \\
\text { Setuju }\end{array}$ & $40 \%$ \\
\hline & & Setuju & $60 \%$ \\
\hline & & $\begin{array}{l}\text { Tidak } \\
\text { Setuju }\end{array}$ & $0 \%$ \\
\hline & & $\begin{array}{l}\text { Sangat } \\
\text { Tidak } \\
\text { Setuju }\end{array}$ & $0 \%$ \\
\hline \multirow[t]{4}{*}{8.} & \multirow{4}{*}{$\begin{array}{l}\text { Model Learning cycle } 5 E \\
\text { berbasis guided discovery } \\
\text { dapat meningkatkan } \\
\text { penguasaan konsep siswa }\end{array}$} & $\begin{array}{l}\text { Sangat } \\
\text { Setuju }\end{array}$ & $31 \%$ \\
\hline & & Setuju & $69 \%$ \\
\hline & & $\begin{array}{l}\text { Tidak } \\
\text { Setuju }\end{array}$ & $0 \%$ \\
\hline & & $\begin{array}{l}\text { Sangat } \\
\text { Tidak } \\
\text { Setuju }\end{array}$ & $0 \%$ \\
\hline
\end{tabular}

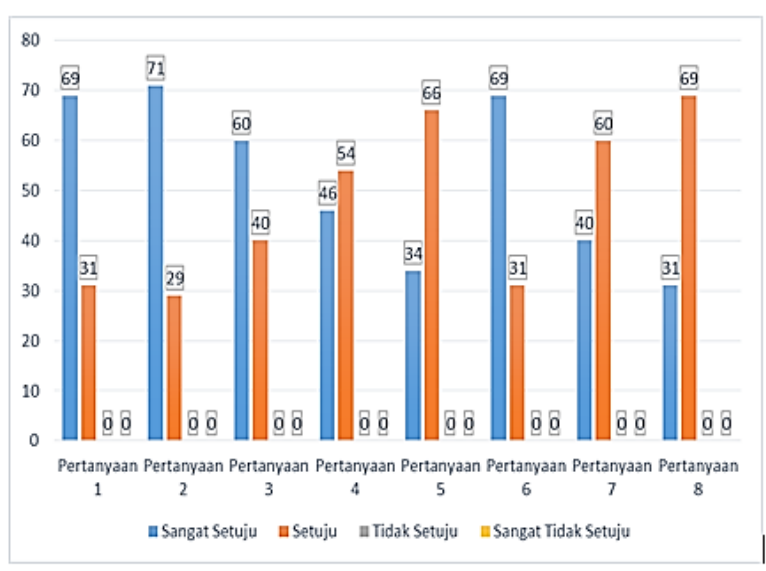

Respon siswa terhadap kegiatan pembelajaran diketahui dari data hasil pengisian angket setelah mengikuti pembelajaran model learning cycle $5 E$ berbasis guided discovery. Angket respon siswa digunakan untuk mengetahui respon, minat, pendapat dan penilaian siswa terhadap pelaksanaan kegiatan belajar mengajar berupa komentar mengenai model pembelajaran learning cycle $5 E$ berbasis guided discovery.

Berdasarkan Tabel 3 dapat dikatahui bahwa seluruh siswa cenderung memberikan respon positif karena $69 \%$ siswa sangat setuju bahwa bahwa pembelajaran model learning cycle $5 E$ berbasis guided discovery melalui metode diskusi dan eksperimen, membuat siswa lebih semangat belajar dengan langsung mengaplikasikan pelajaran atau materi yang didapat; $71 \%$ siswa sangat setuju bahwa model pembelajaran learning cycle $5 E$ berbasis guided discovery membuat siswa lebih berani untuk mengemukakan pendapat-pendapat yang ada dalam pikirannya, sehingga lebih cepat paham terhadap materi yang dipelajarinya; $60 \%$ siswa sangat setuju bahwa model pembelajaran learning cycle $5 E$ berbasis guided discovery membuat siswa lebih aktif dalam kegiatan pembelajaran; $46 \%$ siswa sangat setuju bahwa model pembelajaran learning cycle 5 berbasis guided discovery dapat meningkatkan motivasi belajar siswa; $34 \%$ siswa sangat setuju bahwa model pembelajaran learning cycle $5 E$ berbasis guided discovery membuat siswa lebih mudah mengerjakan soal-soal; $69 \%$ siswa sangat setuju bahwa model pembelajaran learning cycle $5 E$ berbasis guided discovery dengan metode diskusi dan eksperimen menarik dan tidak membosankan; $40 \%$ siswa sangat setuju bahwa model learning cycle $5 E$ berbasis guided discovery melatih kemampuan siswa untuk menyelesaikan masalah sendiri dengan bimbingn guru; $31 \%$ siswa setuju bahwa model pembelajaran learning cycle $5 E$ berbasis guided discovery dapat meningkatkan hasil belajarnya).

Berdasarkan analisis data diatas, disimpulkan bahwa siswa memberikan respon positif dan baik terhadap pembelajaran yang menggunakan model learning cycle $5 E$ berbasis guided discovery. Sesuai dengan pendapat Slavin (2009) yang menyatakan bahwa respon yang baik menunjukkan motivasi siswa terhadap pembelajaran yang baik. Siswa yang termotivasi untuk belajar sesuatu akan menggunakan proses kognitif yang lebih tinggi dalam mempelajari informasi baru itu, siswa akan menyerap dan menyimpan informasi baru itu lebih baik.

Hal ini sesuai dengan pendapat Hudojo (2001)

Gambar 2. Respon Siswa Terhadap Pembelajaran $L C 5 E$. dalam Fajaroh (2007) bahwa ditinjau dari dimensi 
siswa, penerapan model pembelajaran learning cycle $5 E$ berbasis guided discovery memberi keuntungan dan dapat meningkatkan motivasi belajar karena motivasi yang tinggi, memacu siswa untuk terlibat secara aktif dalam proses pembelajaran.

\section{B. Hasil Belajar}

Penerapan pembelajaran leraning cycyle $5 E$ berbasis guided discovery pada uji perangkat, sebelumnya dilaksanakan pretest, dengan tujuan untuk mengetahui pengetahuan awal siswa sebelum mendapat perlakuan pembelajaran. Akhir proses pembelajaran dilakukan posttest dengan tujuan untuk mengetahui pengetahuan siswa setelah mendapat perlakuan pembelajaran model learning cycle $5 E$ berbasis guided discovery. Tes hasil belajar berupa tes pilihan ganda sebanyak 21 soal dan uraian sebanyak 2 soal. Hasil belajar siswa selain tes untuk mengetahui pengetahuan siswa, juga diadakan penilaian sikap dan keterampilan terhadap siswa.

\section{Hasil Belajar Pengetahuan}

Hasil belajar siswa berupa pengetahuan diukur menggunakan instrumen tes hasil belajar. Rekapitulasi tes hasil belajar siswa secara individual serta peningkatannya disajikan dalam Tabel 4 Skor kompersi sesuai dengan Permendikbud No. 81 A

Tabel 4. Analisis Ketuntasan Hasil Belajar

\begin{tabular}{|c|c|c|c|c|c|c|}
\hline $\begin{array}{l}\text { No } \\
\text {. }\end{array}$ & $\begin{array}{l}\text { Sis } \\
\text { wa }\end{array}$ & $\begin{array}{l}\text { Skor } \\
\text { konp } \\
\text { ersi }\end{array}$ & $\begin{array}{l}\text { Pred } \\
\text { ikat }\end{array}$ & \begin{tabular}{|l|} 
Ketunt \\
asan \\
Indivi \\
du
\end{tabular} & \begin{tabular}{l|} 
Skor \\
Pening \\
katan \\
(Gain)
\end{tabular} & Kategori \\
\hline 1. & B1 & 3,8 & A & Tuntas & 0,90 & Tinggi \\
\hline 2. & B2 & 3,7 & $\mathrm{~A}$ & Tuntas & 0,88 & Tinggi \\
\hline 3. & B3 & 3,4 & A- & Tuntas & 0,83 & Tinggi \\
\hline 4. & B4 & 3,2 & $\mathrm{~B}+$ & Tuntas & 0,76 & Tinggi \\
\hline 5. & B5 & 3,2 & $\mathrm{~B}+$ & Tuntas & 0,74 & Tinggi \\
\hline 6. & B6 & 3,7 & $\mathrm{~A}$ & Tuntas & 0,87 & Tinggi \\
\hline 7. & B7 & 3,2 & $\mathrm{~B}+$ & Tuntas & 0,76 & Tinggi \\
\hline 8. & B8 & 3,5 & A- & Tuntas & 0,87 & Tinggi \\
\hline 9. & B9 & 3,5 & A- & Tuntas & 0,85 & Tinggi \\
\hline 10. & B10 & 3,4 & A- & Tuntas & 0,81 & Tinggi \\
\hline 11. & B11 & 3,1 & $\mathrm{~B}+$ & Tuntas & 0,70 & Sedang \\
\hline 12. & B12 & 3,5 & A- & Tuntas & 0,84 & Tinggi \\
\hline 13. & B13 & 3,4 & A- & Tuntas & 0,83 & Tinggi \\
\hline 14. & B14 & 3,8 & $\mathrm{~A}$ & Tuntas & 0,92 & Tinggi \\
\hline 15. & B15 & 3,7 & A & Tuntas & 0,90 & Tinggi \\
\hline 16. & B16 & 3,2 & $\mathrm{~B}+$ & Tuntas & 0,69 & Sedang \\
\hline 17. & B17 & 3,2 & $\mathrm{~B}+$ & Tuntas & 0,69 & Sedang \\
\hline 18. & B18 & 3,0 & B & Tuntas & 0,70 & Sedang \\
\hline 19. & B19 & 3,4 & A- & Tuntas & 0,83 & Tinggi \\
\hline 20. & B20 & 3,7 & $\mathrm{~A}$ & Tuntas & 0,88 & Tinggi \\
\hline 21. & B21 & 3,4 & A- & Tuntas & 0,81 & Tigggi \\
\hline 22. & B22 & 3,0 & B & Tuntas & 0,69 & Sedang \\
\hline 23. & B23 & 3,4 & A- & Tuntas & 0,78 & Tinggi \\
\hline 24. & B24 & 3,8 & $\mathrm{~A}$ & Tuntas & 0,93 & Tinggi \\
\hline 25. & B25 & 3,5 & A- & Tuntas & 0,80 & Tinggi \\
\hline 26. & B26 & 3,1 & $B+$ & Tuntas & 0,70 & Sedang \\
\hline 27. & B27 & 3,0 & $\mathrm{~B}$ & Tuntas & 0,70 & Sedang \\
\hline 28. & B28 & 3,5 & A- & Tuntas & 0,83 & Tinggi \\
\hline 29. & B29 & 3,4 & A- & Tuntas & 0,83 & Tinggi \\
\hline 30. & B30 & 3,3 & $\mathrm{~B}+$ & Tuntas & 0,78 & Tinggi \\
\hline
\end{tabular}

Penerapan Model Pembelajaran Kooperatif Tipe TAI ...

\begin{tabular}{|l|l|l|l|l|l|l|}
\hline 31. & B31 & 3,5 & A- & Tuntas & 0,85 & Tinggi \\
\hline 32. & B32 & 3,5 & A- & Tuntas & 0,85 & Tinggi \\
\hline 33. & B33 & 3,0 & B & Tuntas & 0,70 & Sedang \\
\hline 34. & B34 & 3,0 & B & Tuntas & 0,66 & Sedang \\
\hline 35. & B35 & 3,3 & B + & Tuntas & 0,78 & Tinggi \\
\hline \multicolumn{2}{|l|}{ Rata-rata } & 3,4 & & 0,76 & $\begin{array}{l}\text { Tingg } \\
\text { i }\end{array}$ & \\
\hline
\end{tabular}

Tabel 5. Ketuntasan Indikator THB

\begin{tabular}{|c|c|c|c|c|c|c|}
\hline $\begin{array}{c}\text { N } \\
\mathbf{o}\end{array}$ & $\begin{array}{c}\text { Indik } \\
\text { ator }\end{array}$ & $\begin{array}{c}\text { Skor } \\
\text { kompe } \\
\text { rsi }\end{array}$ & $\begin{array}{c}\text { Pred } \\
\text { ikat }\end{array}$ & $\begin{array}{c}\text { Ketuntasan } \\
\text { Indikator }\end{array}$ & $\begin{array}{c}\text { Skor } \\
\text { Pening } \\
\text { katan } \\
\text { (Gain) }\end{array}$ & $\begin{array}{c}\text { Kate } \\
\text { gori }\end{array}$ \\
\hline 1. & 1 & 2,9 & B- & Tuntas & 0.70 & Sedang \\
\hline 2. & 2 & 3,3 & B + & Tuntas & 0,81 & Tinggi \\
\hline 3. & 3 & 3,1 & B & Tuntas & 0,75 & Tinggi \\
\hline 4. & 4 & 2,9 & B- & Tuntas & 0,67 & Sedang \\
\hline 5. & 5 & 3,3 & B+ & Tuntas & 0,82 & Tinggi \\
\hline 6. & 8 & 2,9 & B- & Tuntas & 0,74 & Tinggi \\
\hline 7. & 9 & 3,3 & B & Tuntas & 0,80 & Tinggi \\
\hline 8. & 10 & 2,9 & B- & Tuntas & 0,68 & Sedang \\
\hline 9. & 11 & 3,1 & B & Tuntas & 0,74 & Tinggi \\
\hline 10 & 12 & 2,9 & B- & Tuntas & 0,73 & Tinggi \\
\hline 11 & 13 & 3,3 & B+ & Tuntas & 0,81 & Tinggi \\
\hline 12 & 6 & 3,5 & B+ & Tuntas & 0,84 & Tinggi \\
\hline 13 & 7 & 3,4 & B+ & Tuntas & 0,83 & Tinggi \\
\hline Rata-rata & & & & 0,76 & Tinggi \\
\hline
\end{tabular}

Pengaruh penggunaan model learning cycle $5 E$ berbasis guided discovery terhadap hasil belajar siswa, dapat diketahui dengan memberikan tes sebanyak dua kali, yaitu berupa pretest (diberikan kepada siswa sebelum dilakukan pembelajaran), dari 35 siswa seluruhnya belum mencapai ketuntasan karena dalam melaksanakan pretest, siswa belum memperoleh pembelajaran materi sistem reproduksi manusia dan posttest (setelah pembelajaran selesai), seluruh siswa sudah mencapai ketuntasan belajar. Pemberian pretest dan posttest bertujuan untuk mengetahui sensitivitas setiap butir soal dan skor peningkatan (gain-score) yang diperoleh setiap siswa.

Analisis ketuntasan individu dan klasksikal tes hasil belajar ditunjukkan pada Tabel 4. Analisis sensitivitas dan ketuntasan indikator dalam tes hasil belajar yang ditunjukkan pada Tabel 5. Setelah melalui analisis butir soal seperti yang disajikan dalam lampiran dapat dikatahui bahwa soal tes hasil belajar yang diterapkan memiliki indeks sensitivitas antara 0.70 1.0. Sesuai dengan ketentuan dari Aiken (1997) yang menyatakan bahwa suatu butir soal dikatakan peka jika indeks sensitivitasnya $\geq 0.30$. Semakin besar harga sensitivitasnya maka makin besar kepekaan butir soal terhadap efek pembelajaran, disimpulkan bahwa butirbutir soal tersebut sangat baik karena memiliki kepekaan/sensitivitasnya yang tinggi terhadap proses pembelajaran yang diterapkan yaitu model learning cycle $5 E$ berbasis guided discovery, dengan demikian butir soal yang diterapkan untuk mengukur ketuntasan belajar siswa, ini dapat digunakan karena memiliki 
sensitivitas yang tinggi.

Tabel 5 juga dikatahui bahwa ketuntasan indikator tes hasil belajar setelah pembelajaran berlangsung adalah 100\%. Sementara sebelum pembelajaran berlangsung ketuntasan indikator berkisar antara $0 \%$ $20 \%$ dengan rata-rata $10 \%$. Secara umum kenaikan ketuntasan untuk semua indikator sebelum dan sesudah pembelajaran meningkat secara bervariasi antara $70 \%$ sampai $100 \%$. Analisis data hasil belajar siswa yang di dasarkan pada ketuntasan individu dan klaksikal pada Tabel 4 menunjukkan setiap siswa telah mencapai nilai posttest yang mencapai bahkan melebihi KKM yaitu 2.88, sehingga ketuntasan belajarnya secara individu sebesar $100 \%$ dan klasksikal sebesar $100 \%$, hal ini sesuai dengan Kriteria Ketuntasan Minimal (KKM) Permendikbud No. 81A Lampiran IV 2013, peserta didik dikatakan tuntas belajarnya secara individu jika skor yang diperoleh minimal 2,66. Berdasarkan ketuntasan individu yang disajikan dalam Tabel 4.4 siswa yang telah tuntas sebesar $100 \%$, semua siswa menggunakan model learning cycle $5 E$ berbasis guided discovery memiliki rata-rata nilai sebesar 85 atau 3,4.

Skor peningkatan hasil belajar (gain-score) konsep siswa disajikan dalam Tabel 4. Skor peningkatan (gain score) yang dicapai setiap siswa berkisar antara 0.66 0,93 dengan rata-rata 0,76 . Sesuai dengan klasifikasi gain dari Savinainen \& Scott (2002), yang menyatakan bahwa skor peningkatan (gain score) tes hasil belajar siswa tersebut tergolong tinggi (high-gain).

Tingginya nilai peningkatn ini menunjukkan bahwa pembelajaran learning cycle $5 E$ berbasis guided discovery ini dapat meningkatkan hasil belajar siswa pada materi sistem reproduksi manusia. dalam mencapai peningkatan hasil belajar siswa juga sejalan dengan penelitian yang dilakukan sebelumnya oleh Czapla (2012) yang menunjukkan bahwa model siklus belajar merupakan model pembelajaran yang sangat cocok diterapkan dalam pembelajaran kimia, karena dapat meningkatkan penguasaan konsep jika siklus belajar diterapkan kepada siswa yang berada dalam taraf operasi formal. peneltian yang dilakukan oleh Rahayuningsih (2012) juga menunjukkan bahwa penggunaan siklus belajar $5 \mathrm{E}$ (leraning cycle 5E) disertai peta konsep dalam pembelajaran sains telah menunjukkan peningkatan kualitas proses siswa dan kualitas hasil belajar siswa. Penelitian yang dilakukan oleh Sayuti (2012) menunjukkan bahwa penerapan model learning cycle $5 E$ dapat meningkatkan sikap ilmiah dan hasil belajar sains biologi kelas XI IPA. Hal ini dapat di lihat pada peningkatan sikap ilmiah siswa, daya serap belajar, ketuntasan individu dan aktivitas siswa. Penelitian yang dilakukan oleh Pratiwi (2014) menunjukkan bahwa yang telah mengikuti pembelajaran dengan

Hasil penelitian ini juga senada dengan hasil

hasil penelitian, yang dilaksanakan pada pembelajaran dengan model Learning Cycle $5 E$ terhadap kompetensi keterampilan hasilnya terdapat perbedaan pada keterampilan proses sebelum dan sesudah diterapkannya model pembelajaran Learning Cycle $5 E$ dengan perbedaan nilai posttest yang lebih tinggi daripada nilai pretest. Kompetensi pengetahuan siswa setelah diterapkannya model pembelajaran Learning Cycle $5 E$ yang ditunjukkan oleh nilai posttest, hasilnya mengalami perbedaan yang signifikan terhadap nilai pretest. Dengan demikian hasil yang didapat dari penelitian ini sangat didukung oleh penelitian-penelitian sebelumnya.

Implementasi pembelajaran model learning cycle $5 E$ berbasis guided discovery pada materi sistem reproduksi manusia dapat disimpulkan bahwa model learning cycle $5 E$ berbasis guided discovery beserta perangkat dapat digunakan dalam pembelajaran untuk meningkatkan hasil belajar siswa pada pembelajaran biologi SMA.

\section{Hasil belajar Sikap}

Penilaian sikap dulu dikenal sebagai penilaian afektif. Aspek afektif berkaitan dengan sikap dan nilai. Analisis ketuntasan hasil belajar sikap dapat dilihat pada Tabel 6

Tabel. 6. Analisi Ketuntasan Hasil Belajar Sikap

\begin{tabular}{|c|c|c|c|c|c|c|}
\hline \multirow{2}{*}{ No } & \multirow{2}{*}{$\begin{array}{l}\text { Nama } \\
\text { Siswa }\end{array}$} & \multicolumn{2}{|c|}{ Nilai Sikap } & \multirow{2}{*}{$\begin{array}{l}\text { Rata- } \\
\text { rata }\end{array}$} & \multirow{2}{*}{ Predikat } & \multirow{2}{*}{$\begin{array}{l}\text { Ketunta } \\
\text { san } \\
\text { Individu }\end{array}$} \\
\hline & & Spiritual & Sosial & & & \\
\hline 1. & B1 & 3,48 & 3,50 & 3,49 & $\begin{array}{c}\text { Sangat } \\
\text { baik }\end{array}$ & Tuntas \\
\hline 2. & B2 & 3,26 & 3,15 & 3,20 & Baik & Tuntas \\
\hline 3. & B3 & 3,35 & 3,07 & 3,21 & Baik & Tuntas \\
\hline 4. & B4 & 3,07 & 3,36 & 3,22 & Baik & Tuntas \\
\hline 5. & B5 & 3,07 & 3,17 & 3,12 & Baik & Tuntas \\
\hline 6. & B6 & 3,39 & 3,35 & 3,37 & $\begin{array}{c}\text { Sangat } \\
\text { baik }\end{array}$ & Tuntas \\
\hline 7. & B7 & 3,13 & 3,06 & 3,09 & Baik & Tuntas \\
\hline 8. & B8 & 3,13 & 3,09 & 3,11 & Baik & Tuntas \\
\hline 9. & B9 & 2,98 & 3,15 & 3,06 & Baik & Tuntas \\
\hline 10. & B10 & 3,07 & 3,20 & 3,14 & Baik & Tuntas \\
\hline 11. & B11 & 3,26 & 3,11 & 3,19 & Baik & Tuntas \\
\hline 12. & B12 & 3,39 & 3,34 & 3,37 & $\begin{array}{c}\text { Sangat } \\
\text { baik }\end{array}$ & Tuntas \\
\hline 13. & B13 & 3,43 & 3,08 & 3,25 & Baik & Tuntas \\
\hline 14. & B14 & 3,06 & 3,03 & 3,04 & Baik & Tuntas \\
\hline 15. & B15 & 3,13 & 3,06 & 3,10 & Baik & Tuntas \\
\hline 16. & B16 & 3,22 & 3,16 & 3,19 & Baik & Tuntas \\
\hline 17. & B17 & 3,22 & 3,10 & 3,16 & Baik & Tuntas \\
\hline 18. & B18 & 3,13 & 3,11 & 3,12 & Baik & Tuntas \\
\hline 19. & B19 & 2,98 & 3,33 & 3,16 & Baik & Tuntas \\
\hline 20. & B20 & 3,43 & 3,28 & 3,35 & $\begin{array}{c}\text { Sangat } \\
\text { baik }\end{array}$ & Tuntas \\
\hline 21. & B21 & 3,09 & 3,12 & 3,11 & Baik & Tuntas \\
\hline 22. & B22 & 3,50 & 3,26 & 3,38 & $\begin{array}{c}\text { Sangat } \\
\text { baik }\end{array}$ & Tuntas \\
\hline 23. & B23 & 3,22 & 3,13 & 3,18 & Baik & Tuntas \\
\hline 24. & B24 & 3,19 & 3,34 & 3,26 & Baik & Tuntas \\
\hline 25. & B25 & 3,07 & 3,03 & 3,05 & Baik & Tuntas \\
\hline
\end{tabular}

Penerapan Model Pembelajaran Kooperatif Tipe TAI ... 


\begin{tabular}{|c|c|c|c|c|c|c|}
\hline \multirow{2}{*}{ No } & \multirow{2}{*}{$\begin{array}{l}\text { Nama } \\
\text { Siswa }\end{array}$} & \multicolumn{2}{|c|}{ Nilai Sikap } & \multirow{2}{*}{$\begin{array}{l}\text { Rata- } \\
\text { rata }\end{array}$} & \multirow{2}{*}{ Predikat } & \multirow{2}{*}{$\begin{array}{l}\text { Ketunta } \\
\text { san } \\
\text { Individu }\end{array}$} \\
\hline & & Spiritual & Sosial & & & \\
\hline 26. & $\bar{B} 26$ & & 3,06 & 3,11 & Da & Tuntas \\
\hline 27. & & & 19 & & & atas \\
\hline 28. & 28 & 24 & 3,06 & 31 & 1 & Tuntas \\
\hline 29. & & & 10 & & Baik & \\
\hline 30. & 0 & 3,44 & 3,29 & 3,37 & $\begin{array}{c}\text { Sangat } \\
\text { baik }\end{array}$ & as \\
\hline 31. & & 3,09 & 3,19 & 21 & & Tuntas \\
\hline 32. & 52 & 13 & 3,09 & 3,1 & Baik & Tuntas \\
\hline 33. & B33 & 3,19 & 3,07 & 3,13 & Baik & Tuntas \\
\hline 34. & B34 & 3,06 & 3,12 & 3,09 & Baik & Tuntas \\
\hline 35. & B35 & 3,39 & 3,37 & 3,38 & $\begin{array}{c}\text { Sangat } \\
\text { baik }\end{array}$ & Tuntas \\
\hline
\end{tabular}

Tabel 6 menunjukkan bahwa penilaian kompetensi sikap melalui observasi, penilaian diri, penilaian "teman sejawat" oleh peserta didik, pada penilaian aspek spiritual dan sosial. Hasil belajar pada kompetensi sikap pada pembelajaran model $5 E$ berbasis guided discovery materi pokok sistem reproduksi manusia dengan enam kali pertemuan terhadap 35 orang siswa dengan skor terendah 2,98 terdapat pada predikat baik dan tertinggi 3,37 terdapat pada predikat sangat baik pada aspek spiritual dan sosial, nilai rata-rata yang diperoleh dari semua aspek dari enam kali pertemuan sebesar 3,19, terdapat pada peredikat baik, berarti secara individu hasil belajar sikap semua siswa tuntas, pada setiap pertemuannya nilai sikap siswa berdasarkan observasi pengamat, penilaian diri sendiri dan penilaian antar teman sesuai dengan Permendikbud No. 81 A Lampiran IV 2013.

\section{Hasil Belajar Keterampilan}

Penilaian kompetensi keterampilan dalam penelitian yang dilakukan melalui penilaian kinerja dan proyek. Analisis ketuntasan belajar keterampilan dapat dilihat pada Tabel 7. Predikat mengacu pada Permendikbud no. $81 \mathrm{~A}$.

Tabel 7. Analisis Ketuntasan Hasil Belajar Keterampilan

\begin{tabular}{|c|c|c|c|c|c|c|}
\hline \multirow{2}{*}{ No } & \multirow{2}{*}{$\begin{array}{l}\text { Nama } \\
\text { Siswa }\end{array}$} & \multicolumn{2}{|c|}{$\begin{array}{c}\text { Nilai } \\
\text { Keterampilan }\end{array}$} & \multirow{2}{*}{$\begin{array}{l}\text { Rata- } \\
\text { rata }\end{array}$} & \multirow{2}{*}{$\begin{array}{l}\text { Predi } \\
\text { kat }\end{array}$} & \multirow{2}{*}{$\begin{array}{l}\text { Ketuntasan } \\
\text { Individu }\end{array}$} \\
\hline & & $\begin{array}{c}\text { Uji } \\
\text { Kehamilan }\end{array}$ & Poster & & & \\
\hline 1. & B1 & 3,63 & 3,75 & 3,69 & $\bar{A}$ & Tuntas \\
\hline 2. & B2 & 3,00 & 3,13 & 3,06 & $\mathrm{~B}+$ & Tuntas \\
\hline 3. & B3 & 3,25 & 3,13 & 3,19 & $\mathrm{~B}+$ & Tuntas \\
\hline 4. & B4 & 3,13 & 3,00 & 3,06 & $\mathrm{~B}+$ & Tuntas \\
\hline 5. & B5 & 3,25 & 3,63 & 3,44 & A- & Tuntas \\
\hline 6. & B6 & 3,75 & 3,63 & 3,69 & $\mathrm{~A}$ & Tuntas \\
\hline 7. & B7 & 3,00 & 3,25 & 3,13 & $\mathrm{~B}+$ & Tuntas \\
\hline 8. & B8 & 3,38 & 3,38 & 3,38 & $\overline{A-}$ & Tuntas \\
\hline 9. & B9 & 3,13 & 3,00 & 3,06 & $\mathrm{~B}+$ & Tuntas \\
\hline 10. & $\overline{\mathrm{B} 10}$ & 3,63 & 3,50 & 3,56 & $\bar{A}$ & Tuntas \\
\hline 11. & B11 & 3,25 & 3,00 & 3,13 & $\mathrm{~B}+$ & Tuntas \\
\hline 12. & B12 & 3,00 & 3,00 & 3,00 & B & Tuntas \\
\hline 13. & B13 & 3,13 & 3,38 & 3,25 & $\mathrm{~B}+$ & Tuntas \\
\hline 14. & B14 & 3,00 & 3,13 & 3,06 & $\mathrm{~B}+$ & Tuntas \\
\hline 15. & B15 & 3,50 & 3,38 & 3,44 & A- & Tuntas \\
\hline 16. & B16 & 3,63 & 3,13 & 3,38 & $\overline{A-}$ & Tuntas \\
\hline
\end{tabular}

\begin{tabular}{|c|c|c|c|c|c|c|}
\hline \multirow{2}{*}{ No } & \multirow{2}{*}{$\begin{array}{l}\text { Nama } \\
\text { Siswa }\end{array}$} & \multicolumn{2}{|c|}{$\begin{array}{c}\text { Nilai } \\
\text { Keterampilan } \\
\end{array}$} & \multirow{2}{*}{$\begin{array}{l}\text { Rata- } \\
\text { rata }\end{array}$} & \multirow{2}{*}{$\begin{array}{l}\text { Predi } \\
\text { kat }\end{array}$} & \multirow{2}{*}{$\begin{array}{l}\text { Ketuntasan } \\
\text { Individu }\end{array}$} \\
\hline & & $\begin{array}{c}\text { Uji } \\
\text { Kehamilan }\end{array}$ & Poster & & & \\
\hline 17. & B17 & 3,00 & 3,25 & 3,13 & $\mathrm{~B}+$ & Tuntas \\
\hline 18. & B18 & 3,00 & 3,13 & 3,06 & $\mathrm{~B}+$ & Tuntas \\
\hline 19. & B19 & 3,38 & 3,00 & 3,19 & $\mathrm{~B}+$ & Tuntas \\
\hline 20. & B20 & 3,00 & 3,00 & 3,00 & B & Tuntas \\
\hline 21. & B21 & 3,25 & 3,00 & 3,13 & $\mathrm{~B}+$ & Tuntas \\
\hline 22. & B22 & 3,13 & 3,13 & 3,13 & $\mathrm{~B}+$ & Tuntas \\
\hline 23. & B23 & 3,25 & 3,13 & 3,19 & $\mathrm{~B}+$ & Tuntas \\
\hline 24. & B24 & 3,38 & 3,38 & 3,38 & A- & Tuntas \\
\hline 25. & B25 & 3,38 & 3,63 & 3,50 & A- & Tuntas \\
\hline 26. & B26 & 3,00 & 3,13 & 3,06 & $\mathrm{~B}+$ & Tuntas \\
\hline 27. & B27 & 3,25 & 3,50 & 3,38 & A- & Tuntas \\
\hline 28. & B28 & 3,13 & 3,00 & 3,06 & $\mathrm{~B}+$ & Tuntas \\
\hline 29. & B29 & 3,50 & 3,38 & 3,44 & A- & Tuntas \\
\hline 30. & B30 & 3,25 & 3,00 & 3,13 & $\mathrm{~B}+$ & Tuntas \\
\hline 31. & B31 & 3,75 & 3,63 & 3,69 & $\mathrm{~A}$ & Tuntas \\
\hline 32. & B32 & 3,38 & 3,00 & 3,19 & $\mathrm{~B}+$ & Tuntas \\
\hline 33. & B33 & 3,25 & 3,00 & 3,13 & $\mathrm{~B}+$ & Tuntas \\
\hline 34. & B34 & 3,25 & 3,25 & 3,25 & $\mathrm{~B}+$ & Tuntas \\
\hline 35. & B35 & 3,88 & 3,63 & 3,75 & A & Tuntas \\
\hline
\end{tabular}

Tabel 7 menunjukkan bahwa hasil belajar pada kompetensi keterampilan pada pembelajaran model learning cycle $5 E$ berbasis guided discovery terhadap 35 orang siswa dengan skor terendah 3.00 dengan predikat $\mathrm{B}$ dan tertinggi 3,75 dengan predikat $\mathrm{A}$, berarti semua tuntas secara individual. rata-rata nilai kelasnya sebesar 3.26 dengan predikat $\mathrm{B}+$, hal ini sesuai dengan Peremendikbud No. 81 A Lampiran IV 2013.

Berdasrkan Permendikbud nomor 66 tahun 2013 Nilai pada tiap kompetensi yang didapatkan menunjukkan bahwa nilai pada setiap keterampilan melalui penilaian kinerja, yaitu penilaian yang menuntut peserta didik mendemonstrasikan suatu kompetensi tertentu dengan menggunakan test praktek, projek, dan penilaian potofolio seperti yang dilakukan siswa pada praktek uji kehamilan dan keterampilan pembuatan poster pada pertemuan kelima dan keenam.

\section{KESIMPULAN}

\section{A. Simpulan}

Berdasarkan temuan-temuan penelitian pada penerapan model learning cycle $5 E$ berbasis guided discovery, maka dapat disimpulkan bahwa penerapan model learning cycle $5 E$ berbasis guided discovery pada pembelajaran biologi materi sistem reproduksi manusia dapat meningkatkan hasil belajar siswa SMA.

\section{B. Saran}

Berdasarkan simpulan dan hasil penelitian didasarkan bahwa dalam menerapkan model pembelajaran learning cycle $5 \mathrm{E}$ berbasis guided discovery supaya memperhatikan pemanfaatan waktu yang dialokasikan.

\section{REFERENSI}

Aiken, L. (1997). Psychology testing and assement. Ninth Edition. USA: Allyn and Bacon. 
Arends, R.I. (2012). Learning to teach. Singapore: McGraw Hill Company

Borich, G.D. (1994). Observation skill for effec teaching. United State of America: Macmillan Publishing company.

Bybee, (2006). The BSCS 5E instructional model: Origins effectivenesess and applications. Colorado Springs: BSCS.

Czapla. (2012). "Analysis of the effect of student cognizanee of the learning cycle in general chemistry". Dessertation University of Oklahoma.

Fajaroh. F. Dan Dasna, I. W. (2007). Pembelajaran dengan model siklus belajar (Learning Cycle). http://lubisgrafura.wordpress. com/2007/09/20/pembelajaran- dengan-modelsiklus-belajar-learning cycle/. Diakses melalui tanggal 1 juni 2014.

Gagne, R. \& Driscoll, M. (1988). Essential of learning for instruction. Englewood Cliffs, NJ: PrenticeHall.

Kusumaningsih, Asep Sutiadi. (2013). "Penerapan model learning cycle 7E untuk meningkatkan keterampilan berpikir kritis dan prestasi belajar siswa SMA pada materi usaha dan energy" Jurnal Pendidikan UPI. Vol. 4, No.1 April 2013. Diakses melalui http://jurnal.upi.edu/penelitian pendidikan/view/ 1681/penerapan model-learning cycle-7Euntuk-meningkatkan-keterampilan -berfikirkritis-dan-prestasi-belajar-siswa-sma-padamateri-usaha-dan-energi.html. Tgl 15 januari 2014.

Mendikbud. (2013). Lampiran IV Permendikbud No. 81 A Tahun 2013 tentang implementasi kurikulum pedoman umum pembelajaran. Jakarta: Kementerian Pendidikan dan Kebudayaan Republik Indonesia

Mendikbud. (2013). Permendikbud No.65 Tahun 2013 tentang Standar Proses Pendidikan Dasar dan Menegah. Jakarta: Kementerian Pendidikan dan Kebudayaan Republik Indonesia

Mendikbud. (2013). No. 662013 Nilai Komptensi Keterampilan. Jakarta: Kementerian Pendidikan dan Kebudayaan Republik Indonesia

Mulyasa, H. E. (2013). Pengembangan dan implementasi kurikulum 2013. Bandung. Remaja Rosda Karya

Pratiwi, W.N \& Supardi, I. (2014). "Penerapan model pembelajaran learning cycle $5 \mathrm{E}$ pada materi fluida statis siswa Kelas X SMA." Jurnal Inovasi Pendidikan Fisika (JIPF). Vol. 03. No. 02, pp. 2014, 143-148.

Qarareh, A.O. (2012). " The effect of using the learning cycle method in teaching science on the education achievement of the sixth graders." International Journal Education Science. Vol. 4 No. 2, pp. 123-132.

Savinainen, A. \& Scott, P. (2002). "The force concept inventory. A tool for monitoring student learning”. Journal of Physic Education. Vol. 37 No. 1, pp. 45.

Slavin, R.E. (2009). Educational physchology theory and pratice. 9th Ed. Massachusetts: Allyn \& Bacon

Thiagarajan, S., Semmel, D.S., \& Semmel, M. I. (1974). Instructional development for training teachers of exceptional children a sourcebook. Bloomington: Indiana University.

Tika, I.K. (2008). "Implementasi strategi 5E dengan bahan ajar bermuatan konseptual sebagau upaya mengubah miskonsepsi dan meningkatkan hasil belajar siswa SMPN 6 Singaraja”. Jurnal Pendidikan dan Pengajaran, Universitas Pendidikan Ghanesa.

Verawati Erie. (2013). Pengembangan perangkat pembelajaran berbasis model learning cycyle $5 E$ untuk meningkatkan penguasaan konsep dan keterampilan berpikir kritis siswa SMK pada materi pokok laju Reaksi. (Tidak dipuplikasikan Tesis Megister Pendidikan tidak dipublikasikan). Universitas Negeri Surabaya.

Watkins, Marley W \& Pacheco, Miriam. (2001). "Interobserver agreement in behavioral research: Importance and Calculation". Journal of Behavioral Education. Vol. 10 No. 4, pp. 205-212. 